\title{
ANALYSIS OF THE TOURISM SECTOR AND QUALITY OF HUMAN RESOURCES' EFFECT ON ECONOMIC GROWTH, INCOME DISPARITY, AND POVERTY LEVELS IN REGENCY/CITY IN BALI PROVINCE, INDONESIA
}

\author{
Jayanthi Ni Kadek Eka, Utama Made Suyana \\ Faculty of Economics and Business, University of Udayana, Bali, Indonesia \\ *E-mail: ekajayanthi33@gmail.com
}

\begin{abstract}
Regencies/cities in the Province of Bali as one of the areas experiencing problems with the rate of economic growth, income disparities and the development of poverty levels are not evenly distributed between regions These problems can be influenced by several factors, such as the tourism sector and the quality of human resources. Research purpose is to analyze the influence of the tourism sector and the quality of human resources on economic growth, income disparities and poverty levels in regencies/cities in Bali Province. The data used is secondary data, namely regency/city panel data in the Province of Bali in 2010-2019 which was obtained from the Central Statistics Agency for the Province of Bali. The data is then analyzed by path analysis using Partial Least Square. The results of the analysis show that the tourism sector and the quality of human resources have a positive and significant effect on economic growth. The tourism sector and economic growth have a positive and significant effect on income disparities, but the quality of human resources has a negative and insignificant effect on income disparities. The tourism sector and economic growth have a negative and insignificant effect on the level of poverty and the quality of human resources has a negative but significant relationship to the level of poverty, while income disparity has a positive and significant effect on the level of poverty. The tourism sector indirectly has no significant effect on income disparities through economic growth, while the quality of human resources indirectly has a significant effect on income disparities through economic growth. The tourism sector and the quality of human resources indirectly have no significant effect on the level of poverty through economic growth and income disparities, while economic growth indirectly does not significantly affect the level of poverty through income disparities in regencies/cities in Bali Province.
\end{abstract}

\section{KEY WORDS}

Tourism sector, human resources, economic growth, income disparity, poverty level.

Regencies/cities in Bali Province have a unique economic structure compared to other provinces in Indonesia. As one of the provinces that have become an icon of Indonesian tourism, regencies/cities in the province of Bali are inseparable from the problem of poverty (Bali Province BPS, 2013:491). According to Santosa (2013) poverty reduction is caused by an increase in income which is not always followed by an increase in economic growth.

During 2015-2019 the percentage of poor people in regencies/cities in Bali Province tends to experience a decline, as presented in Table 1.

Table 1 explains that the percentage of poor people in the Regency/City of the Province of Bali is not evenly distributed in each region. The development of the highest percentage of poor people was in Karangasem Regency at 6.25 percent in 2019, and then followed by Klungkung Regency at 5.40 percent. Buleleng Regency occupies the third position with the highest percentage of poor people at 5.19 percent in 2019. This is different from Badung Regency and Denpasar City which have a lower percentage of poor people compared to the percentage of poor people in Bali Province. In 2019 the percentage of poor people in Badung Regency reached 1.78 percent and the percentage of poor people in Denpasar City was 2.10 percent. Of the nine regencies and cities in Bali Province, there are two regencies/cities with a percentage of poor people below Bali Province, while the other seven regencies have a percentage of poor people above the percentage of poor people in 
Bali Province, which causes an uneven distribution of the percentage of poor people in the Regency/City of Bali Province.

Table 1 - Development of Percentage of Poor Population by Regency/City in Bali Province in 2015-2019

\begin{tabular}{llllll}
\hline \multirow{2}{*}{ Regency/City } & \multicolumn{5}{l}{ Percentage of Poor Population in Bali Province by Regency/City } \\
\cline { 2 - 5 } & 2015 & 2016 & 2017 & 2018 & 2019 \\
\hline Jembrana & 5,84 & 5,33 & 5,38 & 5,20 & 4,88 \\
Tabanan & 5,52 & 5,00 & 4,92 & 4,46 & 4,21 \\
Badung & 2,33 & 2,06 & 2,06 & 1,98 & 1,78 \\
Gianyar & 4,61 & 4,44 & 4,46 & 4,19 & 3,88 \\
Klungkung & 6,91 & 6,35 & 6,29 & 5,86 & 5,40 \\
Bangli & 5,73 & 5,22 & 5,23 & 4,89 & 4,44 \\
Karangasem & 7,44 & 6,61 & 6,55 & 6,28 & 6,25 \\
Buleleng & 6,74 & 5,79 & 5,74 & 5,36 & 5,19 \\
Denpasar City & 2,39 & 2,15 & 2,27 & 2,24 & 2,10 \\
\hline Bali Province & 4,74 & 4,25 & 4,25 & 4,01 & 3,79 \\
\hline
\end{tabular}

Source: Central Bureau of Statistics of Bali Province, 2020.

Table 2 - Development of Gini Ratio by Regency/City in Bali Province in 2015-2019 (in points)

\begin{tabular}{|c|c|c|c|c|c|}
\hline \multirow[t]{2}{*}{ Regency/City } & \multicolumn{5}{|c|}{ Gini Ratio of Bali Province by Regency/City } \\
\hline & 2015 & 2016 & 2017 & 2018 & 2019 \\
\hline Jembrana & 0,22 & 0,23 & 0,26 & 0,30 & 0,30 \\
\hline Tabanan & 0,27 & 0,29 & 0,34 & 0,34 & 0,34 \\
\hline Badung & 0,31 & 0,29 & 0,33 & 0,42 & 0,42 \\
\hline Gianyar & 0,31 & 0,33 & 0,38 & 0,36 & 0,36 \\
\hline Klungkung & 0,33 & 0,34 & 0,39 & 0,38 & 0,38 \\
\hline Bangli & 0,38 & 0,31 & 0,34 & 0,36 & 0,36 \\
\hline Karangasem & 0,35 & 0,29 & 0,34 & 0,33 & 0,33 \\
\hline Buleleng & 0,30 & 0,32 & 0,31 & 0,34 & 0,34 \\
\hline Denpasar & 0,31 & 0,34 & 0,34 & 0,34 & 0,34 \\
\hline Bali Province & 0,38 & 0,37 & & & 0,38 \\
\hline
\end{tabular}

Source: Central Bureau of Statistics of Bali Province, 2020.

Regencies/cities in Bali Province as one of the areas with a fairly high distribution also experience inequality in the acceleration of development between regions. Table 2 describes the development of the Gini ratio in regencies/cities in Bali Province. In 2019, the Gini ratio in Badung Regency was 0.42 points, higher than the Gini ratio in Bali Province of 0.38 points. The high Gini ratio of the Province shows that there is still income inequality between regencies/cities in the Province of Bali. The movement of the regency/city Gini ratio from 2015 to 2019 is very diverse.

In 2019, eight regencies/cities were in the low level of inequality (below 0.4 ), but in general the Gini ratio value in regencies/cities in the Province did not change from 2017 to 2019, which was stagnant at the Gini ratio of 0 . .38 points. The more diverse and diverse the socio-economic conditions of a region can have an influence on the occurrence of income inequality in the region. Income inequality can be affected by economic growth. The economic growth of regencies/cities in Bali Province during 2015 - 2019 tends to decline from 6.03 percent in 2015 to 5.63 percent in 2019, as presented in Table 3.

Table 3 explains the development of the economic growth rate in regencies/cities in Bali Province which experienced a significant decline in 2019. The highest economic growth rate was in Denpasar City at 5.84 percent, followed by Badung Regency at 5.83 percent and the third rank was occupied by Gianyar Regency which has the highest economic growth rate above the economic growth rate of Bali Province of 5.64 percent. Of the nine regencies/cities in the Bali Province, there are still six regencies that have a lower economic growth rate than the Bali Province's economic growth rate.

Disparities in income distribution, poverty, and economic growth can also be affected by the tourism sector. The results of research by Ding Du et al (2016) that the tourism sector has a positive relationship to economic growth. The results of Eric et al's research (2018) that 
the tourism sector can reduce poverty. In 2014-2018, the development of tourism in the Regency/City of the Province of Bali continued to show an increase. However, this increase creates disparities in the distribution of income between each region because the unevenness of tourism activities is felt by all regions in the Regency / City of Bali Province (Yasa \& Arka, 2015).

Table 3 - Development of Economic Growth Rate by Regency/City in Bali Province in 2015-2019, \%

\begin{tabular}{llllll}
\hline \multirow{2}{*}{ Regency/ City } & \multicolumn{5}{l}{ Bali Province Economic Growth Rate by Regency/City } \\
\cline { 2 - 5 } & 2015 & 2016 & 2017 & 2018 & 2019 \\
\hline Jembrana & 6,19 & 5,96 & 5,28 & 5,59 & 5,56 \\
Tabanan & 6,19 & 6,14 & 5,37 & 5,73 & 5,60 \\
Badung & 6,24 & 6,81 & 6,08 & 6,74 & 5,83 \\
Gianyar & 6,30 & 6,31 & 5,46 & 6,03 & 5,64 \\
Klungkung & 6,11 & 6,28 & 5,32 & 5,50 & 5,44 \\
Bangli & 6,16 & 6,24 & 5,31 & 5,50 & 5,47 \\
Karangasem & 6,00 & 5,92 & 5,06 & 5,48 & 5,50 \\
Buleleng & 6,07 & 6,02 & 5,38 & 5,62 & 5,55 \\
Denpasar City & 6,14 & 6,51 & 6,05 & 6,43 & 5,84 \\
\hline Bali Province & 6,03 & 6,33 & 5,56 & 6,33 & 5,63 \\
\hline
\end{tabular}

Source: Central Bureau of Statistics of Bali Province, 2020.

In addition to the tourism sector, the quality of human resources also affects the disparity of income distribution, poverty, and economic growth. Human resources have an important role in the creation of economic and business value (McGregor et al. 2004; Karami et al. 2006). The results of Lonni and Tohir (2012) stated that the quality of human resources has a significant effect on economic growth. The results of research by Abu Kosim (2010) state that the quality of human resources has a significant effect on the level of poverty.

Based on the background of the problems above, the title adopted in this study is "Analysis of the Influence of the Tourism Sector and Quality of Human Resources on Economic Growth, Income Disparities and Poverty Levels in Regencies/Cities in Bali Province".

\section{METHODS OF RESEARCH}

This study uses data with quantitative data types using secondary data from the Central Statistics Agency of Bali Province. The data collection method used in this study is the non-behavioral observation method. The observation points in this study in regencies/cities in the province of Bali used cross section data in a span of 10 years (20102019) with a total of 90 data observation points.

The operational definition of this research variable is 1) the tourism sector which is measured using the contribution of the provision of accommodation and food and drink to GRDP based on constant prices in Regencies/Cities in Bali Province during 2010 - 2019 with percent. 2) The quality of human resources is measured using the average length of schooling in regencies/cities in Bali Province during 2010 - 2019 with units of year. 3) Economic growth is measured using data on the rate of economic growth in regencies/cities in Bali Province during 2010 - 2019 in percent units. 4) Income disparity is measured using the Gini ratio in regencies/cities in Bali Province during $2010-2019$ with units of points. 5) The poverty rate is measured using the percentage of poor people in regencies/cities in Bali Province during $2010-2019$ in percent units.

The analytical technique used in this study is a descriptive analysis of path analysis using Partial Least Square (PLS) and SPSS software. This form of relationship requires an analytical tool that is able to explain the system simultaneously. Kerlinger (2002) states that by using path analysis, direct and indirect effects between variables can be calculated. The steps for path analysis using PLS are as follows:

i) First: designing the model. The first step in path analysis is to design a model based on concepts and theories, namely Figure 1. 


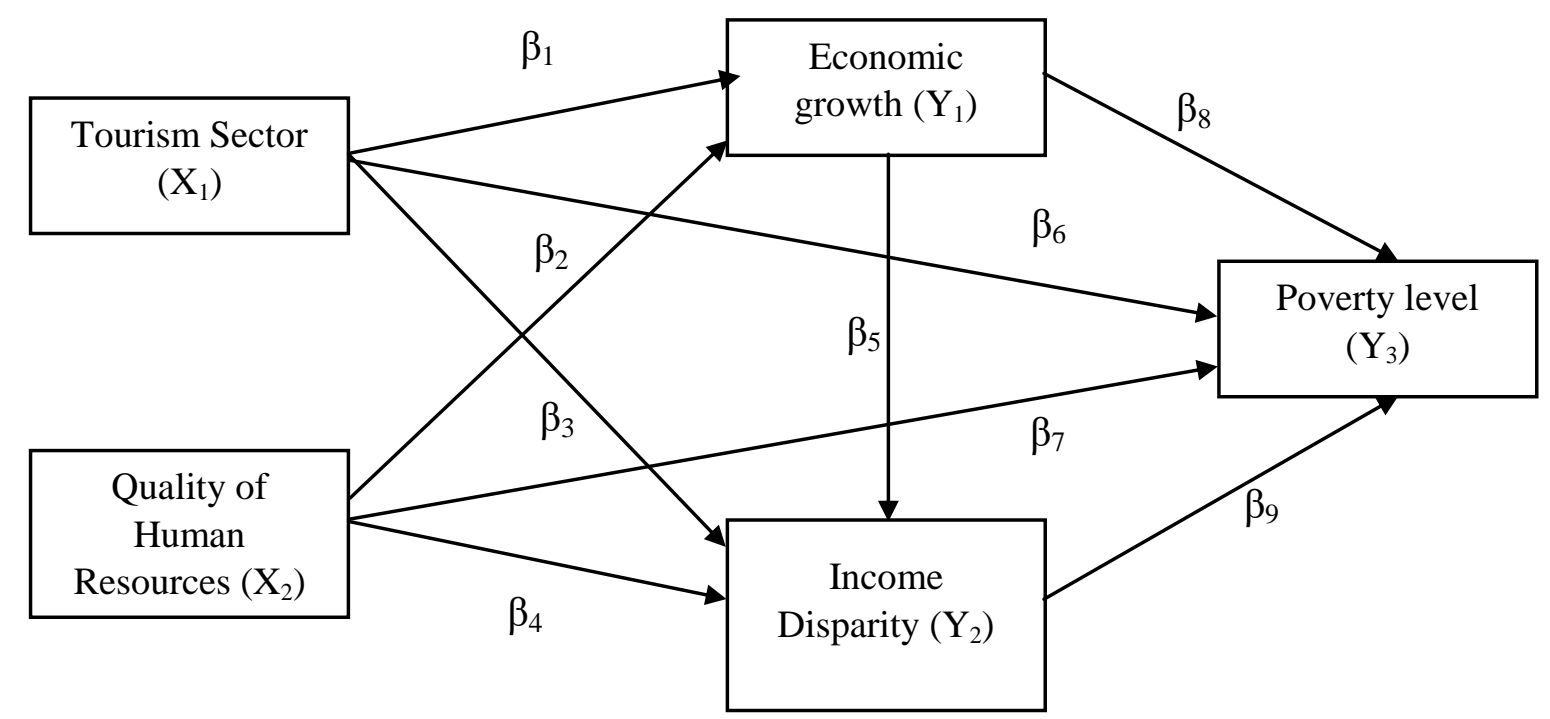

Figure 1 - Path Diagram of Relationship between Variables of the Influence of the Tourism Sector, Quality of Human Resources on Economic Growth, Income Disparities and Poverty Levels in Regencies/Cities in Bali Province

Based on Figure 1 a system of structural equations can be made as follows:

Relationship between $X_{1}$ and $X_{2}$ towards $Y_{1}$

$$
Y_{1}=\beta_{1} X_{1}+\beta_{2} X_{2}+\varepsilon_{1}
$$

Relationship between a $X_{1}, X_{2}$ and $Y_{1}$ towards $Y_{2}$

$$
Y_{2}=\beta_{3} X_{1}+\beta_{4} X_{2}+\beta_{5} Y_{1}+\varepsilon_{2}
$$

Relationship between $X_{1}, X_{2}, Y_{1}, Y_{2}$ towards $Y_{3}$

$$
Y_{3}=\beta_{6} X_{1}+\beta_{7} X_{2}+\beta_{8} Y_{1}+\beta_{9} Y_{2}+\varepsilon_{3}
$$

Where: $X_{1}=$ Tourism Sector (Percent); $X_{2}=$ Quality of Human Resources (Year); $Y_{1}=$ Economic growth (Percent); $Y_{2}=$ Income Disparity (Point); $Y_{3}=$ Poverty level (Percent); $\beta_{1}, \beta_{2} \ldots B_{9}$ is the path coefficient; $\varepsilon_{1}, \varepsilon_{2} \ldots \varepsilon_{3}$ is the error.

ii) Second: Estimating or estimating parameters;

iii) Third: check for the emergence of identification problems;

iv) Fourth step: checking the validity of the model.

The value of Q2 can also be obtained by the formula (Ghozali, 2011):

$$
Q^{2}=1-\left(1-R_{1}^{2}\right)\left(1-R_{2}^{2}\right) \ldots\left(1-R_{k}^{2}\right)
$$

v) Fifth: interpretation of results.

\section{RESULTS AND DISCUSSION}

Descriptive analysis in this study was conducted to obtain an overview of the calculation of the maximum and minimum values, averages and standard deviations in connection with research on the influence of the tourism sector, the quality of human resources, on economic growth, income disparities and poverty levels in regencies/cities in Bali Province. The descriptive analysis in this study is based on panel data, which is a combination of cross section and time series data as shown in Table 4.

Table 4 describes that the tourism sector variable has a maximum value of 29.02 percent located in Badung Regency in 2014 which is a South Bali tourism area and a 
minimum value of 8.53 percent is in Karangasem Regency in 2010 . Then followed by the variable quality of human resources which has a maximum value of 11.23. years in Denpasar City in 2019 and a minimum value of 4.55 years in Karangasem Regency in 2010. Economic growth has a maximum value of 7.64 percent in Badung Regency in 2012 and a minimum value of 4.57 percent in Jembrana Regency in 2010.

Table 4 - Description of Tourism Sector Variables, Quality of Human Resources, Economic Growth, Income Disparities and Poverty Levels in Regencies/Cities in Bali Province in 2010-2019

\begin{tabular}{llllll}
\hline Variable & unit & Minimum & Maximum & Mean & Std. Deviation \\
\hline Tourism Sector & Percent & 8.53 & 29.02 & 18.44 & 6.37 \\
Quality of Human Resources & Year & 4.55 & 11.23 & 7.78 & 1.65 \\
Economic growth & Percent & 4.57 & 7.64 & 6.08 & 0.60 \\
Income Disparity & Gini Index & 0.22 & 0.43 & 0.34 & 0.04 \\
Poverty level & Percent & 1.52 & 7.44 & 4.84 & 1.60 \\
\hline
\end{tabular}

Income disparity has a maximum value of 0.43 points in Badung Regency in 2010 and a minimum value of 0.22 points in Jembrana Regency in 2015 . The poverty rate has a maximum value of 7.44 percent in Karangasem Regency in 2015 and a minimum value of 1.52 percent in 2012. When viewed from the mean or average and standard deviation, the tourism sector has the largest coefficient of variation compared to other variables, while income disparity has the smallest coefficient of variation compared to other variables.

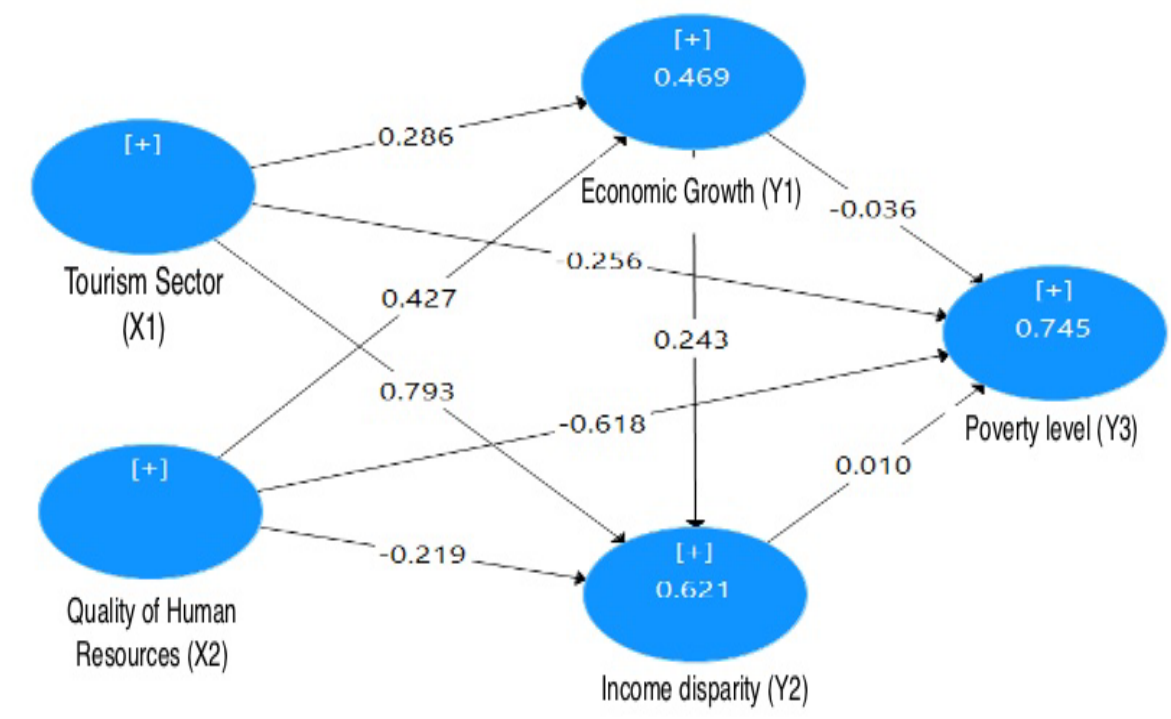

Figure 2 - Path Coefficient of Influence of the Tourism Sector and Quality of Human Resources on Economic Growth, Income Disparities and Poverty Levels in Regencies/Cities in Bali Province, 2010-2019. Source: Research Results, 2021 (processed data).

The structural model in PLS needs to be evaluated using R-square for the dependent variable and its significance value based on the t-values on each path. The structural model of this research can be seen in Figure 2.

Based on Figure 2 regarding the path coefficient between variables, none of which has a path coefficient of more than 1, so there are no symptoms of multicollinearity. Assessing the inner model is tantamount to looking at the relationship between latent variables by looking at the estimation results of the path coefficient and its level of significance.

Table 5 shows the R-square value of 0.496 for the variable economic growth. This means that the variability of economic growth can be explained by the variables of the tourism sector and the quality of human resources by 49.6 percent and the remaining 50.4 percent is explained by other factors. Furthermore, the income disparity variable with an Rsquare of 0.621 means that this variable can be explained by the variables of the tourism 
sector, quality of human resources and economic growth of 62.1 percent and the remaining 37.9 percent is explained by other factors. While the R-square value of the poverty level variable is 0.745 , it means that the variability of the poverty level can be explained by the variables of the tourism sector, quality of human resources, economic growth and income disparity of 74.5 percent and the remaining 25.5 percent is explained by other factors.

Table 5 - R-square Value of Economic Growth Variables, Income Disparities and Poverty Levels

\begin{tabular}{lll}
\hline Variable & R-Square & Information \\
\hline Economic growth & 0,496 & Moderate \\
Income Disparity & 0,621 & Moderate \\
Poverty level & 0,745 & Strong \\
\hline
\end{tabular}

Source: Data processed, 2021.

Based on R2 in Table 5 it can be calculated Q2 or Stone Geiser Q-Square test, namely:

$$
Q^{2}=1-\left\{\left(1-R_{1}^{2}\right)\left(1-R_{2}^{2}\right)\left(1-R_{2}^{2}\right)\right\}=0,951
$$

The result of Q2 calculation is 0.951 so it can be interpreted as having a strong predictive prevalence, so the resulting model is suitable for predicting. The figure of 0.951 can be interpreted that the variation in the poverty rate of 95.1 percent can be explained by variations in the tourism sector variables, the quality of human resources, economic growth and income disparities, while the remaining 4.9 percent is explained by other variables outside the model.

Direct effect analysis can explain the relationship between research variables (latent variables). To determine the direct effect between variables, it can be seen from the results of the analysis of the path coefficients values shown in Table 6.

Table 6 - Coefficient Value of Direct Influence between Tourism Sector Variables and Quality of Human Resources on Economic Growth, Income Disparities and Poverty Levels in Regencies/Cities in Bali Province 2010-2019

\begin{tabular}{lllllll}
\hline No & Variable Relationship & Path Coefficient & Standard Devisiasi & T Statistics & $P$ Values & Information \\
\hline 1. & X1 --> Y1 & 0,286 & 0,129 & 2,225 & 0,027 & Significant \\
2. & X2 --> Y1 & 0,427 & 0,136 & 3,146 & 0,002 & Significant \\
3. & X1 --> Y2 & 0,793 & 0,115 & 6,910 & 0,000 & Significant \\
4. & X2 --> Y2 & $-0,219$ & 0,134 & 1,632 & 0,103 & Not significant \\
5. & Y1 --> Y2 & 0,243 & 0,095 & 2,570 & 0,010 & Significant \\
6. & X1 --> Y3 & $-0,256$ & 0,170 & 1,511 & 0,132 & Not significant \\
7. & X2 --> Y3 & $-0,618$ & 0,134 & 4,624 & 0,000 & Significant \\
8. & Y1 --> Y3 & $-0,036$ & 0,069 & 0,526 & 0,600 & Not significant \\
9. & Y2 --> Y3 & 0,010 & 0,071 & 0,137 & 0,891 & Not significant \\
\hline
\end{tabular}

Source: Lampiran 3

Information:

$X 1=$ Tourism Sector $\quad Y 2=$ Income Disparity

X2 = Quality of Human Resources $\quad$ Y3 = Poverty Level

$Y 1=$ Economics Growth

Thus the results of testing the direct influence hypothesis can be explained as follows:

- The tourism sector has a positive and significant impact on the economic growth of regencies/cities in Bali Province with a $p$-value of 0.027 . This means that if the tourism sector is high, then the average economic growth is also high;

- The quality of human resources has a positive and significant impact on the economic growth of regencies/cities in Bali Province with a p-value of 0.002 . This means that if the quality of human resources is high, then the average economic growth is also high;

- The tourism sector has a positive and significant impact on the income disparity of regencies/cities in Bali Province with a $p$-value of 0.000 . This means that if the 
tourism sector is high, the average income disparity is also high;

- The quality of human resources has a negative and insignificant effect on the income disparity of regencies/cities in Bali Province with a p-value of 0.103 . This means that if the quality of human resources is low, the average income disparity is also low;

- Economic growth has a positive and significant impact on the income disparity of regencies/cities in Bali Province with a $p$-value of 0.010 . This means that if economic growth is high, the average income disparity is also high;

- The tourism sector has a negative and insignificant effect on the poverty level of regencies/cities in Bali Province with a $p$-value of 0.132 . This means that if the tourism sector is low, then the average poverty rate is also low;

- The quality of human resources has a negative and significant effect on the poverty level of regencies/cities in Bali Province with a p-value of 0.000 . This means that if the quality of human resources is low, then the average poverty rate is also low;

- Economic growth has a negative and insignificant effect on the poverty level of regencies/cities in Bali Province with a p-value of 0.600 . This means that if economic growth is low, then the average poverty rate is also low;

- Income disparity has a positive and insignificant effect on the poverty level of regencies/cities in Bali Province with a p-value of 0.891 . This means that if the income disparity is high, the average poverty rate is also high

There are several relationships which are indirect effects between research variables. To find out the indirect effect between variables, it can be seen from the results of the indirect effects value analysis shown in Table 7. It is known that the indirect effect between research variables is not significant but only the indirect effect of the quality of human resources on income disparities through economic growth is significant.

Table 7 - Indirect Coefficient Values between Tourism Sector Variables and Quality of Human Resources on Economic Growth, Income Disparities and Poverty Levels in Regencies/Cities in Bali Province 2010-2019

\begin{tabular}{lllllll}
\hline Variable Relationship & Variable Mediation & Original Sample & Standard Deviation & T Statistics & $P$ Values & Information \\
\hline X1 --> Y2 & Y1 & 0,070 & 0,044 & 1,577 & 0,115 & Not significant \\
X1 --> Y3 & Y1,Y2 & $-0,002$ & 0,067 & 0,029 & 0,977 & Not significant \\
X2 --> Y2 & Y1 & 0,104 & 0,05 & 2,079 & 0,038 & Significant \\
X2 --> Y3 & Y1, Y2 & $-0,170$ & 0,034 & 0,483 & 0,629 & Not significant \\
Y1 --> Y3 & Y2 & 0,002 & 0,018 & 0,128 & 0,898 & Not significant \\
\hline
\end{tabular}

Source: Data processed, 2021.

Information:
$X 1=$ Tourism Sector
X2 = Quality of Human Resources
$Y 1=$ Economics Growth

$$
\begin{aligned}
& Y 2=\text { Income Disparity } \\
& Y 3=\text { Poverty Level }
\end{aligned}
$$

Thus, the results of testing the indirect influence hypothesis can be explained as follows:

1. The tourism sector has an indirect and insignificant effect on income disparities through the economic growth of regencies/cities in Bali Province with a P. Value of 0.115 ;

2. The tourism sector has an indirect and insignificant effect on poverty levels through economic growth and income disparities in regencies/cities in Bali Province with a P. Value of 0.977 ;

3. The quality of human resources has a significant indirect effect on income disparities through the economic growth of regencies/cities in Bali Province with a P. Value of 0.038 ;

4. The quality of human resources has an indirect and insignificant effect on the level of poverty through economic growth and income disparities in regencies/cities in Bali Province with a P. Value of 0.629 ;

5. Economic growth has an indirect and insignificant effect on poverty levels through the income disparity of regencies/cities in Bali Province with a P. Value of 0.898. 


\section{DISCUSSION OF RESULTS}

The Effect of the Tourism Sector on the Economic Growth of Regencies/Cities in Bali Province. The results of data analysis show that the tourism sector has a positive and significant impact on the economic growth of regencies/cities in Bali Province. This means that the higher the contribution of the tourism sector, the rate of economic growth also increases, and vice versa, if the contribution of the tourism sector decreases, the rate of economic growth also decreases. The results of this study are supported by the results of research from Ding Du et al (2016) that the tourism sector has a positive relationship to economic growth. The results of research by Yusuf et al (2007) that the tourism sector has a positive relationship to economic growth.

The Effect of Human Resource Quality on Regency/City Economic Growth in Bali Province. The results of data analysis show that the quality of human resources has a positive and significant impact on the economic growth of regencies/cities in Bali Province. This means that the higher the quality of human resources, the rate of economic growth also increases, and vice versa, if the quality of human resources decreases, the rate of economic growth also decreases. The results of the study (Teguh and Marhaeni, 2019) show that the quality of human resources has a positive and significant effect on economic growth. The results of Lonni and Tohir's research (2012) state that the quality of human resources has a significant effect on economic growth. The results of research by Abu Kosim (2010) state that the quality of human resources has a negative effect on the level of poverty. The results of the research of Haeruddin et al (2020) that the quality of human resources has a positive and significant effect on economic growth.

The Effect of the Tourism Sector on Disparities in Regency/City Income in Bali Province. The results of data analysis show that the tourism sector has a positive and significant effect on income disparities in regencies/cities in Bali Province. This means that the higher the contribution of the tourism sector, the income disparity will also increase, and vice versa, if the contribution of the tourism sector decreases, the income disparity will also decrease. The results of this study are supported by the results of research from Eva and Suyana Utama (2019) who obtained research results which showed that the tourism sector had a significant effect on inequality in income distribution. This means that the increase in the tourism sector every year has not been able to reduce the inequality of income distribution. With the tourism sector making a major contribution to GRDP, in fact only 40 percent of low-income people have not fully enjoyed the benefits of the tourism sector compared to 40 percent of middle-income people and 20 percent of low-income people. So that there are still income disparities in regencies/cities in Bali Province. The government must carry out all policies that can help 40 percent of low-income people enjoy 17 percent of regional income from the tourism sector sektor.

The Effect of Human Resource Quality on Regency/City Income Disparities in Bali Province. The results of data analysis show that the quality of human resources does not significantly affect the income disparity of regencies/cities in Bali Province. This shows that if the quality of human resources has increased, it will not be followed by a significant increase in income disparity. The results of this study are supported by the results of research from Rizza (2019) which states that the quality of human resources has no effect on income disparities. The annual education budget is at least 20 percent of the APBD. Based on data, the average length of schooling in regencies/cities in Bali Province is still below 20 percent. This means that the quality of human resources in regencies/cities in Bali Province is still not ready to compete widely, so there is still income disparity between groups. Vocational and Diploma graduates are expected to be able to shift between sectors, especially in improving the quality of life so as to create income distribution between groups.

The Effect of Economic Growth on Regency/City Income Disparities in Bali Province. The results of data analysis show that economic growth has a positive and significant effect on income disparities in regencies/cities in Bali Province. This means that the higher the rate of economic growth, the income disparity also increases, and vice versa, if the rate of economic growth decreases, the income disparity also decreases. The results of Ratnasari's 
research (2017) obtain the results of research that economic growth has a positive and significant effect on inequality in income distribution. The results of Emi's research (2017) obtain research results that economic growth has a positive and significant effect on inequality in income distribution. Riandoko (2013), Raswita and Made (2013), Ibourk (2013), Szeles (2013), Ali (2014), and Das (2014) who concluded that economic growth partially affects income disparities.

The Effect of the Tourism Sector on the Poverty Level of Regencies/Cities in Bali Province. The results of data analysis show that the contribution of the tourism sector has a negative and insignificant effect on the poverty level of regencies/cities in Bali Province. This shows that if the contribution of the tourism sector has increased, it will not be followed by a significant increase in the level of poverty. The results of research by Robertico (2014), that the tourism sector has no effect on poverty.

The results of this study are supported by research results from Eka Putri (2019) and Ivan (2016) which state that the number of tourism visitors has a negative effect on poverty. This shows that more tourism visits will reduce poverty, this is because many Balinese people work in the tourism sector, it can be proven that tourism is the largest source of income for regencies/cities in Bali Province. From the tourism sector, the Balinese are able to support their lives, there are many tourism places that are able to provide jobs for the Balinese people, from the formal sector or the informal sector.

According to Bryden (1973), tourism development and economic growth have a mutual relationship to alleviate poverty. It is not surprising that tourism in Bali is able to contribute to increasing poverty, this is because of the large number of workers that can be absorbed by the tourism sector. This is due to the role of tourists who visit. With accommodation, tourists can stay for some time and consume in their tourism journey.

The Effect of the Quality of Human Resources on the Poverty Level of Regencies/Cities in Bali Province. The results of data analysis show that the quality of human resources has a significant effect on the poverty level of regencies/cities in Bali Province, but the quality of human resources has a negative relationship with the poverty level. This means that if the quality of resources increases, it will reduce the level of poverty. The results of research by Abu Kosim (2010) stated that the quality of human resources has a negative effect on the level of poverty.

The government must continue and develop various programs aimed at reducing poverty such as increasing budget allocations to improve the welfare of the poor by providing the poor with guarantees in the fields of health, education and food availability. the average level of schooling is also a factor that affects the high and low number of property crimes, the government also needs to develop more adequate and quality educational facilities, especially educational facilities in remote villages so that educational facilities can be felt equally both in the city and in the village and providing scholarships for underprivileged students.

The Effect of Economic Growth on the Poverty Level of Regency/City in Bali Province. The results of data analysis show that the rate of economic growth has a negative and insignificant effect on the poverty level of regencies/cities in Bali Province. This shows that if the rate of economic growth has increased, it will not be followed by a significant increase in the poverty rate. The results of this study are supported by the results of research from Sodik et al (2019) that economic growth has a negative effect on poverty. The results of Lonnie et al (2018) research that economic growth has a negative effect on poverty. The results of research by Lisa, et al (2019) that economic growth has a negative effect on poverty.

This is also supported by research conducted by Wongdesmiwati (2009), which found that there is a negative relationship between economic growth and poverty levels in accordance with the proposed hypothesis, so the hypothesis in this study can be accepted. An increase in economic growth will reduce the level of poverty. This relationship shows the importance of accelerating economic growth to reduce poverty levels.

The Effect of Income Disparity on Regency/City Poverty Levels in Bali Province. The results of data analysis show that income disparity has a significant effect on the poverty level of regencies/cities in Bali Province. This means that the higher the level of income 
disparity, the poverty level will also increase, otherwise if the income disparity decreases, the poverty level will also decrease. The results of this study are supported by the results of research from Desthy (2020) which states that income disparity has a significant effect on poverty levels. Income distribution is one aspect of poverty that needs to be considered because in essence income distribution is a measurement of relative poverty. There are two categories of poverty levels, namely relative poverty and absolute poverty. Absolute poverty is a condition in which a person cannot fulfill his basic needs such as clothing, food, shelter, education and health or in other words his income is not sufficient for his living expenses. While relative poverty is a calculation of poverty based on the proportion of income in an area or region (Sukirno, 2013).

The Indirect Effect of the Tourism Sector on Income Disparities through Regency/City Economic Growth in Bali Province. Based on the results of the analysis, it is known that the tourism sector has an indirect and insignificant effect and has a positive relationship on income disparities through economic growth in regencies/cities in Bali Province, it shows that the tourism sector does not have a significant impact on income disparities if it is through economic growth, but the tourism sector has a positive relationship to income disparity through economic growth, meaning that if the contribution of the tourism sector increases, it will reduce the level of income disparity through growth.

Indirect Effect of Human Resource Quality on Income Disparities through Regency/City Economic Growth in Bali Province. Based on the results of the analysis, it is known that the quality of human resources indirectly has a significant effect on income disparities through the economic growth of regencies/cities in Bali Province, meaning that the influence of the quality of human resources on further economic growth will have a significant impact on income disparities.

According to Todaro (2006), states that the higher the rate of economic growth, the income distribution pattern will be more unequal due to an increase in the aggregate saving rate followed by increased investment and economic growth caused by rich people having a larger savings ratio than people. the poor. If the reason for the inequality caused by growth is only measured by the savings ratio, it is deemed irrelevant because the portion of the savings to GDP ratio is only about 20 percent. This is one of the reasons why economic growth is not sufficiently influential on the inequality of income distribution. In addition, according to the theory of Harrod Domar and Neo classical, states that the role of capital is very important for the economic growth of a region where areas with high potential will have high economic growth as well. Because of the difference in potential that makes one region unequal with other regions.

Indirect Effect of the Tourism Sector on Poverty Levels through Disparities in Regency/City Income in Bali Province. The results of data analysis show that the contribution of the tourism sector indirectly has no significant effect on the level of poverty through income disparities, it shows that the tourism sector does not have a significant impact on the level of poverty through income disparities in regencies/cities in Bali Province..

Indirect Effect of Quality of Human Resources on Poverty Levels through Disparities in Regency/City Income in Bali Province. The results of data analysis show that the quality of human resources does not indirectly have a significant effect on the level of poverty through income disparities, it shows that the quality of human resources does not have a significant impact on the level of poverty through income disparities in regencies/cities in Bali Province.

Indirect Effect of Economic Growth on Poverty Levels through Disparities in Regency/City Income in Bali Province. The results of data analysis show that indirect economic growth does not have a significant effect on poverty levels through income disparities in regencies/cities in Bali Province. Basically, the more people work, the lower the poverty rate because people have income to meet their daily needs (Yacoub, 2012).

According to the World Bank (2016), most of the workers in the Regency/City of Bali Province work in the informal sector with low incomes so that it causes an even distribution of people's income, but the distribution is in a low economic class. The income that most people get can be said to be below the average so that people who work are included in the unemployment criteria. So it refers to the results of this study where high unemployment 
causes economic equity. The distribution that occurs is not the expected equalization because the intended distribution is the distribution of income in the low economy class.

\section{CONCLUSION}

Based on data analysis and discussion, it can be concluded several things as follows.

1) The tourism sector and the quality of human resources have a positive and significant impact on economic growth in regencies/cities in Bali Province;

2) The tourism sector and economic growth have a positive and significant effect on income disparities, but the quality of human resources has a negative and insignificant effect on income disparities in regencies/cities in Bali Province;

3) The tourism sector and economic growth have a negative and insignificant effect on the poverty level and the quality of human resources has a negative but significant relationship to the poverty level, while income disparity has a positive and significant effect on the poverty level in regencies/cities in Bali Province;

4) The tourism sector indirectly has no significant effect on income disparities through economic growth, while the quality of human resources indirectly has a significant effect on income disparities through economic growth in regencies/cities in Bali Province;

5) The tourism sector and the quality of human resources indirectly have no significant effect on the level of poverty through economic growth and income disparities, while economic growth indirectly does not significantly affect the level of poverty through income disparities in regencies/cities in Bali Province.

\section{SUGGESTIONS}

Based on the results of the analysis and conclusions above, it is necessary to have other alternative sectors to be balanced with other sectors and shifting or changes from the tourism sector which are developed by other sectors operationally that can affect the rate of economic growth, overcome income disparities between groups and reduce poverty levels, provided that there is no leaving the tourism sector as the leading sector in regencies/cities in Bali Province, by making equal distribution in each regency that has low employment opportunities in order to open up business opportunities or employment opportunities that can gather more local workers in the area. The development design between top downbottom up is carried out in stages and development should be focused on programs that concern the lives of many people, especially to alleviate poverty.

\section{REFERENCES}

1. Ali, Sharafat, 2014. Inflation, Income Inequality and Economic Growth in Pakistan: A Cointegration Analysis. International Journal of Economic Practices and Theories. Vol. 4, No. 1, Summer 2014. pp. 33-42.

2. BPS. 2013. Pemantauan Kemiskinan di Indonesia: Metode Pengukuran and Perkembangannya. Hal. 35.

3. Das, Samarjit dkk., 2014. Economic growth and income inequality: examining. Journal of Quantitative Economics, Vol. 12, No.1. Summer 2014. pp. 86- 95.

4. Ding Du, Pin Ng, Alan A. Lew. 2016. Tourism and Economic Growth. Article in Journal of Travel Research. DOI: 10.1177/0047287514563167.

5. Desthy Fadila. 2020. Analisis Faktor-Faktor Yang Mempengaruhi Disparitas Pendapatan Di Provinsi Jawa Barat. Publikasi IImiah. Universitas Muhammadiyah. Surakarta.

6. Eric Tchouamou Njoya, and Neelu Seetaram. 2018. Tourism Contribution to Poverty Alleviation in Kenya: A Dynamic Computable General Equilibrium Analysis. Journal of Travel Research 2018, Vol. 57(4) 513-524.

7. Eka Putri. 2019. Pengaruh Sektor Pariwisata Terhadap Kemiskinan Di Provinsi Bali. Jurnal Ilmiah. Universitas Brawijaya.

8. Eva Krismiyanti, Ni Made and Made Suyana Utama. 2019. Pengaruh Sektor Pariwisata 
and Kualitas Sumber Daya Manusia Terhadap Kesempatan Kerja and Ketimpangan Distribusi Pendapatan. E-Jurnal EP Unud, 9 [6]: 1261 - 1289. E-Jurnal Ekonomi Pembangunan Universitas Udayana, Vol.9.No.6.

9. Haeruddin Saleh, Batara Surya, Despry Nur Annisa Ahmad and Darmawati Manda. 2020. The Role of Natural and Human Resources on Economic Growth and Regional Development: With Discussion of Open Innovation Dynamics. J. Open Innov. Technol. Mark. Complex. 2020, 6, 103; doi:10.3390/joitmc6040103.

10. Ibourk, Aomar \& Jabrane Amaghouss, 2013. Inequality in Education and Economic Growth: Empirical Investigation and Foundations - Evidence 66 Jurnal Ekonomi Pendidikan and Kewirausahaan from MENA Region. International Journal of Economics and Finance Vol. 5, No. 2. Summer 2013. pp. 111-124.

11. Ivan Zulhendra. 2016. Faktor-Faktor Yang Mempengaruhi Kemiskinan Di Provinsi Bali (2011-2015). Universitas Islam Indonesia. Yogyakarta.

12. Lisa Nansadiqa, Raja Masbar, M. Shabri Abd. Majid. 2019. Does Economic Growth Matter For Poverty Reduction In Indonesia?. East African Scholars Publisher, Kenya. Vol-2, Iss-2 (February, 2019): 46-51.

13. Lonni K. Stevans, David N. Sessions. 2018. The Relationship Between Poverty, Economic Growth, and Inequality Revisited. Journal of Income Distribution.

14. Raswita, Ngaka Putu Mahesa \& Made Suyana Utama, 2013. Analisis Pertumbuhan Ekonomi and Ketimpangan Pendapatan Antar Kecamatan di Kabupaten Gianyar. EJurnal EP Unud Vol. 2 No. 3. Summer 2013. pp. 119-128.

15. Riandoko, Benedictus dkk., 2013. Pengaruh Pertumbuhan Ekonomi, Share Sektor Industri and Pertanian Serta Tingkat Jumlah Orang Yang Bekerja Terhadap Ketimpangan Wilayah Antar Kabupaten/Kota Di Jawa Tengah Tahun 2002-2010. Jurnal Ekonomi Vol. 2 No. 1. Summer 2013. pp. 1-14.

16. Rizza Umaroh. 2019. Pengaruh Pertumbuhan Ekonomi, Kualitas Sumber Daya Manusia and Tingkat Pengangguran Terhadap Ketimpangan Pendapatan Di Jawa Timur. Universitas Jember.

17. Robertico Croes. 2014. The role of tourism in poverty reduction: an empirical assessment. Tourism Economics, 2014, 20 (2), 207-226 doi: 10.5367/te.2013.0275.

18. Santosa, Budi. 2013. Pengaruh Pendapatan Asli Daerah and Dana Perimbangan daerah Terhadap Pertumbuhan, Pengangguran and Kemiskinan 33 Provinsi di Indonesia. Jurnal Ekonomi and Bisnis. Vol. 5, No. 2 Juli 2013.

19. Suyana, Utama. 2012. Aplikasi Analisis Kuantitatif. Buku Ajar. Denpasar: Fakultas Ekonomi Universitas Udayana.

20. Sodik Dwi Purnomo and Istiqomah. 2019. Economic Growth and Poverty: The Mediating Effect of Employment. Jejak Vol 12 (1) (2019): 238-252

21. Szeles, Monica Raileanu, 2013. Re-examining the relationship between economic growth and inequality in the New Member States. Qual Quant. Summer 2013. Pp. 2799-2813.

22. Todaro, Michael P. and Stephen C. Smith. 2006. Pembangunan Ekonomi (edisi kesembilan, jilid I). Jakarta: Erlangga.

23. Wongdesmiwati. (2009). Pertumbuhan Ekonomi and Pengentasan Kemiskinan Di Indonesia: Analisis Ekonometrika.

24. World Bank (2016). Ketimpangan yang Semakin Lebar. Jakarta: World Bank.

25. Yasa, A. O. I. K., \& Arka, S. (2015). Pengaruh Pertumbuhan Ekonomi and Disparitas Pendapatan Antardaerah Terhadap Kesejahteraan Masyarakat Provinsi Bali. Jurnal Ekonomi Kuantitatif Terapan, 8(1), 63-71.

26. Yacoub, Y. (2012). Pengaruh Tingkat Pengangguran terhadap Tingkat KemiskinanKabupaten/Kota di Provinsi Kalimantan Barat Yarlina. Reposty Polned, 8(3), 176-158.

27. Yusuf Akan, İbrahim Arslan, Cem. 2007. The Impact of Tourism on Economic Growth: TheCase of Turkey. Journal of Tourism, Volume IX. 